\title{
Appropriate Technologies for Improving Yield and Income of Small Holders Growing Rice Paddy in Rainfed Low Lands of Agro-Biodiversity Hotspots in India
}

\author{
Syed Abubacker Siddick \\ Natural Resources Management, Hand in Hand India, Kanchipuram, India \\ Email: siddicka@gmail.com
}

How to cite this paper: Siddick, S.A. (2019) Appropriate Technologies for Improving Yield and Income of Small Holders Growing Rice Paddy in Rainfed Low Lands of Agro-Biodiversity Hotspots in India. Agricultural Sciences, 10, 1497-1505. https://doi.org/10.4236/as.2019.1011110

Received: January 6, 2019

Accepted: November 26, 2019

Published: November 29, 2019

Copyright () 2019 by author(s) and Scientific Research Publishing Inc. This work is licensed under the Creative Commons Attribution International License (CC BY 4.0).

http://creativecommons.org/licenses/by/4.0/ (c) (i) Open Access

\begin{abstract}
Rainfed paddy production accounts for $30 \%$ of rice production in India and supports the nutrition of some of India's poorest farmers. Agro-biodiversity hotspots in India such as Kollihills are rich in genetic variability of economically important staple crops such as rice, millets and tubers inhabited by tribal malayali farmers who largely depend on rice as food for their subsistence. Poor agronomic practices, inadequate water and fertilizer management in growing improved rice varieties resulted in a 50\% yield reduction compared to yields obtained from improved package of practices of similar farming situation. Farmers participatory research conducted by M. S. Swaminathan Research Foundation, India and University of Alberta Canada, in rice paddy cultivation in two seasons of subsequent years 2012 and 2013 showed that adoption of appropriate technologies in rainfed low land paddy help small farmers reaching doubled their yield and income than control.
\end{abstract}

\section{Keywords}

Lowland Paddy, Kolli Hills, Appropriate Technologies

\section{Introduction}

Rice is the staple food crop for $60 \%$ of the world's population. Asia currently accounts for $60 \%$ of the global population, $92 \%$ of the world's rice production and $90 \%$ of the global rice consumption [1]. Rice is economically and nutritionally important crop to millions of small farmers growing it on millions of hectares (ha) and grown in Asia for the last 7000 years. Current paddy production 
in South Asia is increased by $300 \%$, compared to the Green Revolution in the late 1960s [2]. India and Bangladesh are major rice-growing countries in the South Asia. In the past five decades, majority of the rice production increased because of yield growth, with harvested area increased from 50 million ha in the late 1960s to 60 million ha now [3]. South Asia accounts 37\% of the world rice area. Approximately, 50\% of the rice growing area in South Asia is rain fed [4]. Rain fed paddy production accounts for $30 \%$ of the rice production in India and supports the nutrition of some of India's poorest farmers [5] [6] [7].

Rain fed lowland rice cultivation is found in South and South-East Asia, which accounts $25 \%$ of the total world's rice area. In India, lowland rice is cultivated in about 14.4 million ha, which accounts for $32.4 \%$ of the total area under rice crop in the country [8]. Sustained production of rice paddy is the key for the food security in South Asia [9]. In 2004, the average rice yield in the world and Asia was 3.97 and 4.08 MT/ha, respectively. In Indian state of Tamil Nadu, paddy production accounts for the three quarter of state's food grain production [10]. Rain fed low land farmers are typically challenged by poor soil quality, drought or flood conditions [11]. Farmers growing rice in rainfed paddy systems are operating at sub-optimal levels of production with $90 \%$ of them having yields that are lower than India's average production of 2.1 MT/ha. This variation in the production is due to lack of technology used in rice paddy cultivation. This rain fed yield gap is the result of a number of production constraints, which include socio-economic, technological and biophysical [12]. Notably, farmers lack range of practices including planting density, weeding, fertilization and water management to support improved varieties which are identified as serious constraints in improving rain fed rice yields [13]. Rice research with appropriate technologies for rainfed low land farmers has a key role for reaching higher yields and income, especially in agro-biodiversity hotspots where there is genetic erosion of staple crops existing.

\section{Background}

The production gains can be achieved by bridging the yield gaps of rice with the currently available technologies [14]. Studies show that the accumulated stock of technologies for rainfed rice production was able to increase yield by $30 \%$ to $40 \%$. Constraints to high yield can be classified into two categories: those that affect potential of the crop under farmer's environment, and those that affect farmer's ability and willingness to achieve the yield potential [15]. The first constraint can be addressed through adoption of higher yielding varieties and improved fertilizer and management practices [16] [17]. The second constraint can be addressed through participatory research and demonstrations. For example, Thakur [12] put forth the need for the development of more accessible, problem-based, cost effective and area-specific technologies for rainfed rice production. Drought stress is the largest constraint to rice production in rainfed systems. In Asia, it affects 10 million ha of upland rice and over 13 million ha of 
rain fed lowland rice [18]. Higher paddy yield in the rainfed lowland can be achieved by using appropriate technologies including water management, Integrated Fertilizer Management (IFM), Integrated Pest Management (IPM) concluded that all yield attributing characters in rainfed rice, increased significantly with the increase in levels of Nitrogen $(\mathrm{N})$ from 40 to $100 \mathrm{~kg} / \mathrm{ha}$ in fine rice [19] [20]. Many research findings have shown that neither inorganic fertilizers nor organic sources alone can result in sustainable productivity where the inorganic fertilizer provides nutrients and the organic fertilizer mainly increases soil organic matter and improves soil structure and buffering capacity of the soil [21] [22]. Researchers have demonstrated the beneficial effect of Integrated Nutrient Management in mitigating the deficiency of many secondary and micronutrients [8].

Most of the yield improvement research has focused on rainfed rice paddy systems in Eastern India, but there is also significant amount of rainfed rice paddy production for subsistence in other parts of India including Kolli Hills regions in Tamil Nadu, southern India. The Kolli Hills region has unique soil and climatic characteristics. However, there is a lack of practical knowledge about improved practices appropriate for rainfed paddy rice cultivation in this agro-biodiversity hotspot. Agricultural land-use in the Kolli Hills can be classified into three types: 1) spring-fed valley lands, mainly under paddy, 2) rainfed lands, allocated for millets and cassava, and 3) land on the valley fringes, under pineapple, coffee, pepper and other crops. Two crops of rice are commonly cultivated annually in the spring-fed valley lands [23]. The present study aims to narrow the knowledge gap in the paddy rice cultivation of Kolli Hills. Therefore, the primary objective of the study is to compare yields and production economics of rainfed paddy rice grown in the Kolli Hills under traditional practices and improved practices.

\section{Materials and Methods}

\subsection{Data Collection}

Field level data was collected from the farmers, under farmers practice and improved practice in the Kharif and Rabi season for the two consecutive years 2012 and 2013. Twenty paddy farmers were participated in the Yield Enhancement experiment in both the season and allocated 0.1 acre $\left(40 \mathrm{~m}^{2}\right.$ plots) for each farmers practice and improved practice. Paddy varieties used under the YET experiment is chosen after a mutual discussion between the farmers and scientist. The paddy varieties, White ponni and Co-50 is used in Kharif season and $I R-20$ is used in the Rabi season. Information related to cost incurred on nursery raising, land preparation, transplanting, weeding, fertilizer and pesticide application, harvest, packing and labors involved were recorded for analysis.

\subsection{Methods}

Yield Enhancement experiment (YET) in rainfed paddy crop involves package of 
scientific practices in seed selection, seedlings transplanting, weeding, integrated nutrient management, pest management and post harvest storage. The Characteristics of traditional methods of paddy rice cultivation in Kolli hills are high seeding rate, use of untreated seed, raising seedlings in a nursery without a raised bed, transplanting more seedlings/hill with less spacing, lack of fertilization and lack of water management. YET were conducted for both Kharif (JuneOctober) and Rabi season (December-April) paddy crop over a period of two years, under the APM project (Alleviating Poverty and Malnutrition in Agro Bio-diversity Hotspots), to study the potential changes in yield and income using improved scientific practices (IP) and traditional farmers practice (FP). The package of practices was summarized in Table 1.

Seeds selection and seed treatment: Required quantity $\left(1.5 \mathrm{~kg} / 40 \mathrm{~m}^{2}\right)$ of paddy seeds was selected using viability test (TNAU method) by addition of salt in the container of seeds soaked in water (till a hen's egg float in the water) and chaffy seeds were removed. The seeds were then soaked in water for $24 \mathrm{~h}$ inoculated with $100 \mathrm{~g}$ of Azospirillum and $100 \mathrm{~g}$ of Phospobacterium obtained from the Department of Agriculture, Kolli Hills and allowed to sprout overnight.

Nursery field: Raised bed nurseries of $2 \mathrm{~m}$ length, $75 \mathrm{~cm}$ weight and $10 \mathrm{~cm}$ height were made and the sprouted paddy seeds were spread over them.

Table 1. Summary of farmer's practice and improved practices in rice cultivation.

\begin{tabular}{|c|c|c|}
\hline Cultivation practice & Farmers practice & Improved practice \\
\hline 1) Seed rate & $150-200 \mathrm{~kg} / \mathrm{ha}$ & $45-50 \mathrm{~kg} / \mathrm{ha}$ \\
\hline 2) Seed treatment & Nil & $\begin{array}{l}\text { 1) Selecting viable seeds using } \\
\text { salt water soaking method } \\
\text { 2) Azospirillum and } \\
\text { Phosphobacterium seed treatment }\end{array}$ \\
\hline 3) Nursery beds & $\begin{array}{c}\text { Raised flat } \\
\text { bed nurseries }\end{array}$ & $\begin{array}{l}\text { Raised beds of } 10 \mathrm{~cm} \text { height } \\
\text { for every } 2 \mathrm{~kg} \text { of seed }\end{array}$ \\
\hline 4) Fertilizer in nursery & Nil & DAP application $2 \mathrm{~kg} / 4 \mathrm{~m}^{2}$ of land \\
\hline 5) Transplanting space & Nil & $20 \times 10 \mathrm{~cm}$ between row and plant \\
\hline 6) No of plants/hill & $5-6$ & $2-3$ \\
\hline 7) Fertilizer in main field & $\begin{array}{c}\text { Complex } \\
\text { fertilizer/green leaves }\end{array}$ & $\begin{array}{l}\text { Split dose of fertilizer application: } \\
\text { green leaves + 10:10:10 NPK at basal, } \\
\text { 5:0:0 @ tillering and 5:0:0 at booting stages } \\
\text { using urea, superphosphate and potash }\end{array}$ \\
\hline 8) Weeding & Manual & Manual + kono weeder \\
\hline 9) Water management & Nil & $\begin{array}{l}\text { Controlled water management. } \\
\text { Plots of } 25 \mathrm{~m}^{2} \text { with handmade water } \\
\text { drainage passage between plots }\end{array}$ \\
\hline 10) Pest management & $\begin{array}{l}\text { Chemical or } \\
\text { no pesticides }\end{array}$ & $\begin{array}{l}\text { Vasambu (Acorus calamus) }+ \text { ash (1:9) } \\
\text { application for Earhead bug, Neem oil } \\
\text { soap solution as a pest repellent, } \\
\text { and use of pheromone trap. }\end{array}$ \\
\hline
\end{tabular}

Note: The same farmers repeatedly observed for results in both Kharif and Rabi seasons. 
Di-ammonium phosphate (DAP) application in nursery fields: DAP $2 \mathrm{~kg}$ with crushed neem cake $(250 \mathrm{~g})$ was applied in the nursery beds 4 days prior to pullout the seedlings for transplanting.

Main field preparation: Uniform-size plots of $25 \mathrm{~m}^{2}$ were made, separated with handmade furrows and ridges, which allows water to flow through or stop whenever needed. Locally available Nochi leaves, castor leaves were dumped in each plots and allowed to get rotted. Basal fertilizer of 10:10:10 NPK/40 $\mathrm{m}^{2}$ calculated and applied using straight fertilizers (urea, superphosphate and potash), 5:0:0 NPK as top during the tillering $\left(35-40^{\text {th }}\right.$ day) and 5:0:0 at booting stage (90 $-100^{\text {th }}$ day).

Transplanting: 2 - 3 seedlings per hill were transplanted on the $30^{\text {th }}$ day (Rabi \& Kharif) with the spacing of $20 \mathrm{~cm}$ between the rows and $15 \mathrm{~cm}$ between the plants.

Weeding: Mostly hand weeding was carried out twice one at the $25^{\text {th }}$ day after transplanting and the other during $45-50^{\text {th }}$ day. Kono weeders were used for weeding by women.

Water management: In experimental plots, water was allowed to stay and not to free flow between the plots. Fertilizer was applied when the plots were wet. Plots were allowed to dry during water and pest repellent's application and stopped water flow a week before the harvest, which was not maintained in the control plots.

Plant protection: Neem oil soap solution sprayed during $25^{\text {th }}, 50^{\text {th }}$ and $75^{\text {th }}$ day after transplanting and vasambu (Acorus calamus) powder applied along with ash (1:9 ratio) during heavy infestation of Ear head bugs in both experimental and farmer fields. Pheromone traps were used during Kharif 2012 for attracting yellow stem borer moths.

Harvest: IR-20/ C0-50 were harvested in $110^{\text {th }}$ day after transplanting, while white ponni was harvested in $125^{\text {th }}$ day. In all the 20 cases experimental plots get harvested and threshed like farmer's plot. Both fresh weight and dry weight of harvested paddy were measured and noted.

\section{Results and Discussion}

\subsection{Yield Enhancement Trial of Paddy in Rabi Season}

Table 2 elucidates the comparison of farmers practice and improved practice of paddy cultivation in the Rabi season for the two consecutive years 2012 and 2013. The paddy variety, IR-20 is used under both farm management practices and each being experimented in 20 farmer's field with $430 \mathrm{sq} \cdot \mathrm{m}$ of land in two following years. Paddy yield from improved practices was higher by $27.1 \%$ in 2012 and $25.4 \%$ in 2013, compared to farmers practice. The extra cost involved in production process per one hectare of land in improved practice is $1.5 \%$ in 2012 and $10.5 \%$ in 2013. The net income generated in one hectare of land in improved practice is $97.9 \%$ and $58.1 \%$ higher compared to farmers practice, in 2012 and 2013, respectively. 
Table 2. Comparative yield result of paddy in the years 2012 and 2013.

\begin{tabular}{ccccccc}
\hline & \multicolumn{3}{c}{ IR-20 (2012) } & \multicolumn{3}{c}{ IR-20 (2013) } \\
\cline { 2 - 7 } Particulars & $\begin{array}{c}\text { Farmer's } \\
\text { Practice }\end{array}$ & $\begin{array}{c}\text { Improved } \\
\text { practice }\end{array}$ & $\begin{array}{c}\text { Significance } \\
\text { level }\end{array}$ & $\begin{array}{c}\text { Farmer's } \\
\text { Practice }\end{array}$ & $\begin{array}{c}\text { Improved } \\
\text { practice }\end{array}$ & $\begin{array}{c}\text { Significance } \\
\text { level }\end{array}$ \\
\hline Yield (kg/ha) & 2659 & 3379 & $* * *$ & 2702 & 3388 & $* * *$ \\
Cost of cultivation (Rs/ha) & 39,051 & 39,619 & & 37,174 & 41,076 & $* * *$ \\
Gross income (Rs/ha) & 53,179 & 67,579 & $* * *$ & 54,044 & 67,752 & $* * *$ \\
Net income (Rs/ha) & 14,128 & 27,960 & $* * *$ & 16,870 & 26,676 & $* * *$ \\
\hline
\end{tabular}

Note: ${ }^{* *}$ refers to significance at 0.01 level. The significance level is derived from two-sample test with equal variance.

For producing one quintal of paddy in Rabi season, the cost involved in improved practice is $20.2 \%$ and $11.9 \%$ lower compared to farmers practice, in 2012 and 2013, respectively (Figure 1).

\subsection{Yield Enhancement Trial of Paddy in Kharif Season}

Table 3 explains the comparison of farmers practice and improved practice of paddy cultivation in the kharif season for the two consecutive years 2012 and 2013. The paddy variety, White ponni is used by all (20) farmers under both farm management practices in 2012, while only 10 farmers used white ponni and the other 10 farmers used the CO-50 variety in 2013, because of delay in rain and farmers preference in getting alternate fine variety for consumption than white ponni. In 2012, the improved practices witnessed with $24.0 \%$ higher yield compared to farmers practice, with only additional $10.3 \%$ cost incurred during production process and attributed to $41.1 \%$ addition net income. In 2013, again the improved practices shows positive results of higher yield compared to farmers practices. From the Table 3, it is evident that the yield benefits is higher in CO-50 compared to White ponni in improved practices, with less cost of cultivation and more net income. For producing one quintal of paddy in Kharif season, the cost involved in improved practice is $12.5 \%$ in 2012 (for White ponni) and $16.1 \%$ in 2013 (for CO-50) lower compared to farmers practice, while there is no significant differences for White ponni in 2013 (Figure 2).

\section{Conclusion}

Agriculture is the livelihood for the rural poor in agro-biodiversity hotspot and that rice paddy being the staple crop, help alleviating poverty and ensure sustainable availability of food for the food-insecure population. Appropriate farmer friendly technologies are required to improve yield and income of rainfed small holder in agro-biodiversity hotspots like Kolli Hills. It is evident from the study that with adoption of appropriate technologies and an additional cost of Rs. 2500 to 3000/Ha, farmers could earn Rs. 15,000 - 20,000/Ha more income when compared with farmers practice in kollihills, an agro biodiversity hotspot. 
Table 3. Yield performance of paddy compared for years 2012 and 2013.

\begin{tabular}{|c|c|c|c|c|c|c|c|c|c|}
\hline \multirow[b]{2}{*}{ Particulars } & \multicolumn{3}{|c|}{ White Ponni (2012) } & \multicolumn{3}{|c|}{ White Ponni (2013) } & \multicolumn{3}{|c|}{ CO-50 (2013) } \\
\hline & $\begin{array}{l}\text { Farmer's } \\
\text { Practice }\end{array}$ & $\begin{array}{l}\text { Improved } \\
\text { practice }\end{array}$ & $\begin{array}{c}\text { Significance } \\
\text { level }\end{array}$ & $\begin{array}{l}\text { Farmer's } \\
\text { Practice }\end{array}$ & $\begin{array}{l}\text { Improved } \\
\text { practice }\end{array}$ & $\begin{array}{c}\text { Significance } \\
\text { level }\end{array}$ & $\begin{array}{l}\text { Farmer's } \\
\text { Practice }\end{array}$ & $\begin{array}{l}\text { Improved } \\
\text { practice }\end{array}$ & $\begin{array}{c}\text { Significance } \\
\text { level }\end{array}$ \\
\hline Yield (kg/ha) & 3320 & 4117 & $* * *$ & 3619 & 4293 & $* * *$ & 3473 & 4268 & $* * *$ \\
\hline Cost of Cultivation (Rs/Ha) & 36,852 & 40,656 & $* * *$ & 35,840 & 42,385 & $* * *$ & 37,989 & 40,187 & $* * *$ \\
\hline Gross Income (Rs/Ha) & 66,394 & 82,350 & $* * *$ & 72,371 & 85,857 & $* * *$ & 69,456 & 85,363 & $* * *$ \\
\hline Net Income (Rs/Ha) & 29,541 & 41,694 & $* * *$ & 36,531 & 43,472 & * & 31,468 & 45,176 & $* * *$ \\
\hline
\end{tabular}

Note: ${ }^{* *}$ and ${ }^{\star}$ refers to significance at 0.01 and 0.10 level. The significance level is derived from two-sample test with equal variance.

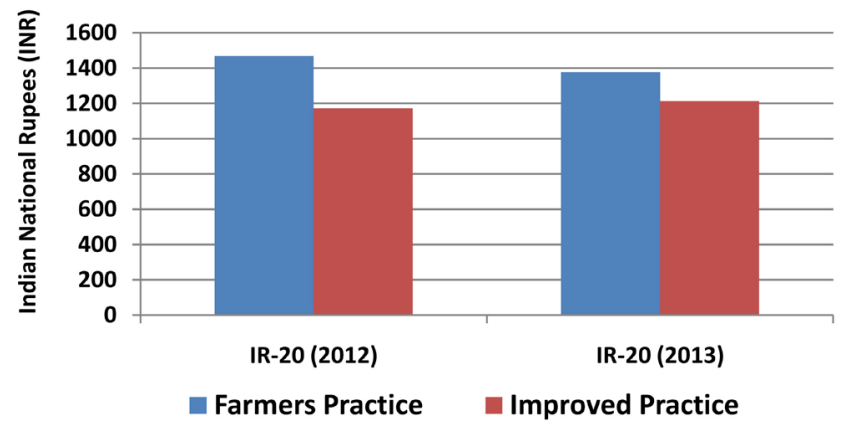

Figure 1. Cost benefit ratio compared for both farmers and improved cultivation practice.

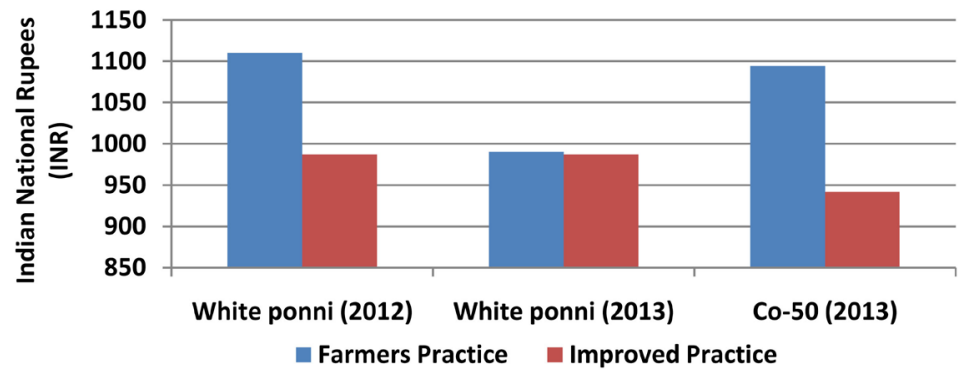

Figure 2. Cost benefit compared for both farmer and improved practices in Kharif season.

It is evident from the field trials that improved practices yielded $20 \%$ more on an average compared with regular farmer practices.

\section{Acknowledgements}

We acknowledge the Funding Agency IDRC-Canada, Dr. Miles Dick, Dr. Varghese of University of Alberta-Canada for guiding me, Paddy farmers research group of Kolli Hills, (Alleviating Poverty and Malnutrition in Agro bio-diversity hotspots of India-project of MSSRF, Chennai), whom took part in the study for the two consecutive years in both kharif and rabi seasons and field technicians Mr. Jayakumar, Mr. Ramesh babu, Mr. yuvaraj, Mr. Chelladurai involved in field observation, yield calculations and harvest. 


\section{Conflicts of Interest}

The author declares no conflicts of interest regarding the publication of this paper.

\section{References}

[1] IRRI (2014) Rice in South Asia, Mohanty. Rice Today, 13, 42.

[2] IRRI (2014) The Importance of Rice. http://www.knowledgebank.irri.org/ericeproduction/Importance_of_Rice.htm

[3] M.S. Swaminathan Research Foundation (MSSRF) (2002) Rural and Tribal Women in Agro Biodiversity Conservation. Food and Agriculture Organization (FAO) RAP Publication, 2002/08. FAO Regional Office for Asia and the Pacific, Bangkok.

[4] Dawe, D., Pandey, S. and Nelson, A. (2010) Emerging Trends and Spatial Patterns of Rice Production. In: Pandey, S., Byerlee, D., Dawe, D., Dobermann, A., Mohanty, S., Rozelle, S. and Hardy, B., Eds., Rice in the Global Economy: Strategic Research and Policy Issues for Food Security, IRRI, Los Baños, Philippines, 15-35.

[5] Singh, K.M., Jha, A.K., Meena, M.S. and Singh, R.K.P. (2012) Constraints of Rainfed Rice Production in Eastern India: An Overview.

http://ssrn.com/abstract $=2061953$

https://doi.org/10.2139/ssrn.2061953

[6] Singh, A., Kumar, R. and Kang, J.S. (2014) Tillage System, Crop Residues and Nitrogen to Improve the Productivity of Direct Seeded Rice and Transplanted Rice. Current Agriculture Research, 2, 14-29. http://www.agriculturejournal.org/?p=757 https://doi.org/10.12944/CARJ.2.1.03

[7] Singh, K., Kumar, V., Saharawat, Y.S., Gathala, M., Ladha, J.K., et al. (2013) Weedy Rice: An Emerging Threat for Direct-Seeded Rice Production Systems in India. Rice Research: Open Access, 1, 106. https://doi.org/10.4172/jrr.1000106

[8] Hossain, M., Bennett, J., Mackill, D. and Hardy, B. (2009) Progress in Crop Improvement Research. International Rice Research Institute, Los Baños, Philippines, $112 \mathrm{p}$.

[9] Bishwajit, G., et al. (2013) Self-Sufficiency in Rice and Food Security: A South Asian Perspective. Agriculture \& Food Security, 2, 10.

https://doi.org/10.1186/2048-7010-2-10

[10] Swaminathan, M.S. (1989) New Technology: Problems and Potentialities in Agricultural Development in India. In: Shah, C.H., Ed., Policy and Problems, Orient Longman, 451-486.

[11] Rice Knowledge Management Portal (RKMP). Courtesy: TNRRI, Aduthurai. http://www.rkmp.co.in/content/rainfed-lowland-rice-eco-system

[12] Thakur, J (1994) Rice Production Constraints in Bihar (India). Paper Presented at the Workshop on Rice Research Prioritization in Asia, 21-22 February 1994, IRRI, Philippines.

[13] Perret, S.R., Thanawong, K., Basset-Mens, C. and Mungkung, R. (2013) The Environmental Impacts of Lowland Paddy Rice: A Case Study Comparison between Rainfed and Irrigated Rice in Thailand. Cahiers Agricultures, 22, 369-377. https://doi.org/10.1684/agr.2013.0663

[14] Shenoi, P.K. and Mandal, B. (1986) Transfer of Technology for Increasing Yields of Rainfed Research, IRRI, Philippines.

[15] Barker, R. (1979) Adoption and Production Impact of New Rice Technology: The 
Yield Constraints Problems. In: Farm Level Constraints to High Rice Yield in Asia, IRRI, Philippines.

[16] Hossain, M. and Fischer, K.S. (1995) Rice Research for Food Security and Sustainable Agricultural Development in Asia: Achievements and Future Challenges. GeoJournal, 35, 286-298. https://doi.org/10.1007/BF00989136

[17] Singh, V.P. and Singh, R.K. (2000) Rainfed Rice: A Sourcebook of Best Practices and Strategies in Eastern India. International Rice Research Institute, 292 p.

[18] Pandey, S., Bhandari, H. and Hardy, B. (2007) Economic Costs of Drought and Rice Farmers. Coping Mechanisms: A Cross Country Comparative Analysis. IRRI, Manila

[19] Prasad, D., Singh, J.P., Singh, J.K. and Bharti, V. (2003) Effect of Irrigation and Nitrogen on Growth and Yield of Early Rice (Oryza sativa L). RAU J Res, 13, 148-150.

[20] Prasad, C., et al. (1986) Operational Research Project on Rice in India. In: Progress in Rainfed Lowland Rice, IRRI, Philippines.

[21] Jobe (2003) Integrated Nutrient Management for Increased Rice Production in the Inland Valleys of the Gambia. Proceedings of the Second Biennial Regional Rice Research Review, WARDA Proceedings Series, 1, 35-41.

[22] Satyanarayana, V., Prasad, P.V., Murthy, V.R.K. and Boote, K.J. (2002) Influence of Integrated Use of Farmyard Manure and Inorganic Fertilizers on Yield and Yield Components of Irrigated Lowland Rice. Journal of Plant Nutrition, 25, 2081-2090. https://doi.org/10.1081/PLN-120014062

[23] Kumaran, M. (2004) Assessment of Development Interventions of M.S. Swaminathan Research Foundation in Kolli Hills Using Geographical Information Systems. Department of Rural Development, Gandhigram Rural Institute, Gandhigram Deemed University, Tamil Nadu, India. 